\title{
RISK MANAGEMENT AND FINANCIAL PERFORMANCE OF MANUFACTURING FIRMS IN NIGERIA
}

\author{
Gideon Tayo \\ Akinleye $^{1}$ \\ Comfort Temidayo \\ Olanipekun $^{2+}$
}

\author{
${ }^{1,2}$ Department of Accounting, Ekiti State University, Ado-Ekiti, Nigeria. \\ 'Email:Gideon.akinleye@eksu.edu.ng Tel: 08036677803 \\ 'Email:Comfort.olanipekun@elsu.edu.ng Tel:08030414641
}

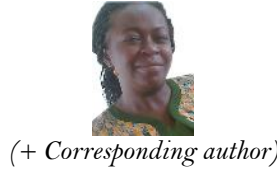

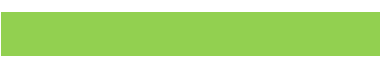

Article History

Received: 8 September 2021 Revised: 23 November 2021 Accepted: 13 December 2021 Published: 28 December 2021

\section{Keywords}

Risk

Risk management

Financial performance

Manufacturing firm

Risk management cycle

Liquidity risk

Market risk.

JEL Classification:

\begin{abstract}
The current study investigated risk management and financial performance of manufacturing firms. Specifically, the study analyzed liquidity risk and market risk effect on after tax profit of manufacturing establishment in Nigeria. The study employed panel data over the period spanning from 2010-2019 across 10 firms. Secondary data were gathered through the annual reports of the selected firms. Correlation analysis and panel-based estimation techniques were used. The outcome showed that liquidity risk positively and significantly affect profit after tax while market risk (measured by interest rate risk) negatively and insignificantly affect profit after tax of sampled firms quoted in Nigeria. This study concluded that efficient and effective risk management will positively affect performance of quoted firms in Nigeria, most specially management of internal risk such as the liquidity risk. Hence, firms should build an internal control system flexible in nature to harness the benefit of internal risk management and also normalize the negative effect of external risk such as the interest rate on performance.
\end{abstract}

Contribution/Originality: The primary contribution are findings that liquidity risk positively and significantly affect profit after tax while interest rate risk negatively and significantly affect profit after tax of quoted manufacturing firms in Nigeria.

\section{INTRODUCTION}

Risk management as part of business management function is argued to be an essential element to be considered in the contemporary business world. According to Ugwuanyi and Ibe (2012) the method of planning, leading, organising and directing the operation of a firm to be able to reduce the outcome of risk on a firm's performance is very essential. Mugenda, Momanyi, and Naibei (2012) also is of the opinion that prioritizing and managing risks is becoming increasingly important to a firm has it assist in the ability to adjust to an ever-changing and global business environment. Risks are now amplifying as a result of globalisation and it management is indispensable to the success of a firm (Ironkwe \& Osaat, 2019). A firm cannot function without taking measured risks. Not all risk is bad, some degree of risk must be considered in order to growth or avoid stagnation. In as much there is risk, its management will be is required.

Effective management of risk tend to maximize the benefit of a risky circumstances and minimizing the adverse consequence of such risk. A firm is profitable, when the income generated surpass the direct and indirect costs expended in generating income. The wealth of a shareholder is maximized when the firm witnessed growth and 
stability in dividend payment or capital gain arising from increase in the wealth of the firm's market share, Ajibola, Wisdom, and Qudus (2018). Understanding the business risks help in guiding firm assets and reducing avoidable costs is very vital in a business. A business risk is a firm's risk on capital, earnings, incidental losses and also operational, financial, strategic and other risks.

Effective management of risk can be regarded as one means of providing assurance of a sound investment to stakeholders. Risk management major purpose is the evading of a significant surprise or a result that the firm did not project either good or bad. Organization is able to achieve its financial targets through risk management. Effective management of risk intermittently evaluate and identifies risks and bringing down trauma that can affect the firms. Coleman (2006) emphasized that the ability to excellently manage risk is the only and most important feature separating manufacturing firm that are feasible, productive and viable in the long run from firms that are not feasible. An efficient risk management scheme, which includes but not limited to risk monitoring, education on cyber security programs, internal audit can as well help the firm to recognize and prepare by using analytics to ascertain violation patterns and investigating cyber-controls in a rhythmic flow (Miller, Huelsman, Clark, \& Sokolovic, 2015).

Risk management should follow risk management cycle, in risk management procedure, one must master the strategic objectives then keep up with the present situation of the organization, this will help in identifying inherent risk of the organisation. Afterward, risk assessment which comprises of risk analysis and evaluation is carried out followed by risk reporting (threat and opportunity), decision, risk treatment, residual risk reporting and monitoring (Farrah, 2011) Organizations are to be proactive in managing risk, monitor continually and consciously in a way it relates with the firm strategic objectives. The management of risk is a requisite fragment of the business, it tends to boost the chances of accomplishment and likewise lessen losses possibility and chances of not attaining the overall organisation goal (Alarm, 2002).

Manufacturing firm is essential in achieving new invention, processes, and technologies (Coleman, 2006). Manufacturing firms have been involved in risk management earlier than the industrial revolution each era this has brought new threat and opportunities (Miller et al., 2015). Financial risk can cripple manufacturing company ability to realise enough returns to its shareholders. To check against financial risk in an organization, the management must understudy and be aware of his area of susceptibleness. A number of studies have assessed the effects of risk management on financial risk of manufacturing firms in Nigeria. Most of these studies focused largely on the banking sector of the economy. For instance, Adeusi, Akeke, Adebisi, and Oladunjoye (2013); Yahaya, Lamidi, Kutigi, and Ahmed (2015) assessed the correlation between risk management Practices and bank financial performance in Nigeria, in addition majority of the studies does not incorporate the uniqueness across sampled firms in their analysis, as most of the study do not fully explore panel data analysis. Hence, this study is to analyze the effect of risk management on financial performance of manufacturing companies in Nigeria. Precisely, the study is to analyzed the:

(i) Impact of liquidity risk on profitability of manufacturing firms in Nigeria.

(ii) Impact of market risk on profitability of manufacturing firms in Nigeria.

\section{LITERATURE REVIEW AND HYPOTHESES DEVELOPMENT}

\subsection{Conceptual Review}

2.1.1. Risk Management

Gallati (2003) defines risk as a situation whereby an organization is liable to disaster, or a situation where chances of divergence from a desired result is high. Acerbi (2008) describes risk as anticipation for danger, negatively unexpected predicament to occur. It can also be referred to as negative digression from the plan. In relation to business, risk is the chance that a situation either predictable or not may lead to unsuitable overall effect on the objectives of the organisation. Risk management involve embracing an efficient and dependable method in 
managing organization risk. Res, Sa, and Gemechu (2016) are of the opinion that risk management consists of several steps, that allow for constant progressive decision by pinpointing, communicating, tracking risks and investigating variance in an organization. Stanton (2012) suggests a comprehensive method like identifying threats, unequivocal examination of possible action either to eradicate, accept or alleviate the identified danger.

Management of risk call for a process of organizing business activities in such a way that gives positive result while guiding against the unfavourable and unexpected suitation that could hinder the desirable result. Mugenda et al. (2012) explained that risk management focus on optimum risk tradeoff and organisation perpetually seek type of risk to be reduced or increased and measures to curtail such. As stated by Njogo (2012), management of risk involves identifing, measuring, ranking and managing available resources to reduce and check the effect of such unfavourably situation (Njogo, 2012). Risk management is the ability to foresee risks and embark on proactive measure to mitigate against business main objective working toward returns maximation and costs reduction (Madembu, Namusonge, \& Sakwa, 2015).

Risk management includes activities that business carried out which aims at minimizing or eliminating all categories of risks (Ezeosa, 2011). Kassi, Rathnayake, and Edjoukou (2019) and Erin, Emoarehi, Jonah, and Ame (2017) identifies liquidity risk, market risk, reputational risk, credit risk, strategic and operational risk as common risk to all businesses.

\subsubsection{Liquidity Risk}

It involves anticipation of negative influence on the interests of shareholders, customers and other stakeholders of an organisation arising from the inability to fulfill current cash obligations in a timely and cost-efficient way (Muriithi, 2016). This is the inability of the organisation to meet it financial obligation due to insufficient revolving cash. According to Yousfi (2014), the likelihood that the firm's will be helpless in fulfilling its duty as well as inability to reinvest on assets at maturity and still avoiding undesirable expenses is called liquidity risk.

\subsubsection{Market Risk}

It is the prospect which a firm experiences loss due to adverse global price movement in the financial markets. Market risk is a vital part of financial risk since it is systematic in nature which cannot be discount by diversification of investment but can be abated using suitable hedging tactics (Kassi et al., 2019). Koch and MacDonald (2006) is of the opinion that risk includes variables associated with financial market like risk on interest rate, risk on foreign exchange and risk on stock price. It is an adverse change due to uncertainty in the economy.

\subsubsection{Risk Management Cycle}

The risk management cycle also called continuous risk management procedure involves the presentation of risk management process in a continuous manner. Antonio and Barbara (2013) defined risk management process as a concept of identifying, treating and then managing risk. This is an ongoing process and actions needed to be taken to reduce adverse effect of risk on an organization (Farrah, 2011). Van Staveren (2009) and Farrah (2011) listed five stages of managing risk: defining the objectives; recognizing the risks; appraising the risks; bearing in mind replacements and choosing means of treating the risk; executing and revising stage. There are still other common views on the risk management cycle that explained it identification, evaluation, ranking, treatment and monitoring (Antonio \& Barbara, 2013).

Figure 1 below explained the risk management cycle from the risk identification, risk evaluation, risk ranging, risk treatment and monitoring. 


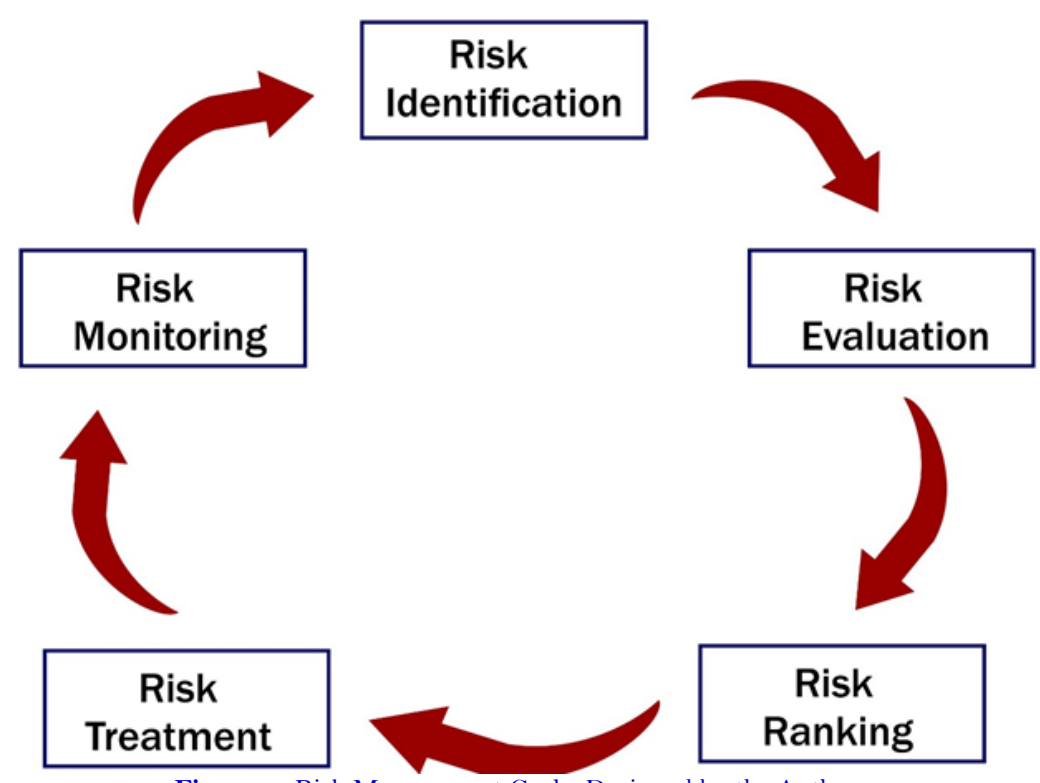

Figure-1. Risk Management Cycle, Designed by the Authors.

\subsubsection{Risk Identification}

This involves identifying the threats and uncertainties associated with organization objective. It entails cataloging likely risks by using breakdown structure, arranging them with the details and entered into a project risk $\log$ or risk register. With this, it is easier the related team to recognize and measure potential threat to the organization.

\subsubsection{Risk Evaluation}

This is the estimation of possibility and consequences of each risk to figure out the area of utmost need. Factors such as time lost, decrease in returns, image loss and stringency of influence are all importantly considered in risk evaluation. Risk can be classified into high and low risk. As identified base on their effect those that placed organization on standstill and those with minor effect. Also, this step includes the outline of risk to documents, policies, procedures and business procedures. This help to discover shared problem across board and restrategise for a better future management purpose.

\subsubsection{Risk Ranking}

This involves arranging the analyzed risk by weighting both the possibility of its manifestation and the potential consequence on the organization. This means that the risk with highest probability and potential effect takes the most priorities while the risk with the lowest likelihood and potential effect takes the least priority. As such, the process helps in determine where the areas to be focused by the team. Also, it allows organization to have a general view of the risk exposure of the whole organization

\subsubsection{Risk Treatment}

This involves exploring the team wealth efficiently in either unravelling or at least mitigating the risk. It requires discovery the desirable means, like "men and money", and essential leverage needed by the organisation. Information dissemination and training should not be left out. Also, meetings instituted that everyone can discuss regarding risk and the solution proffers.

\subsubsection{Risk Monitoring}

At this stage, the proposal must have been established it functionality and effectiveness. Notable fluxes or revision required must have been recognised. Under the manual system, monitoring happens through industrious 
worker who keep close watch on total risk components. But, in a computerized environment, whole risk framework is being watched by the digitalised system. Any change is immediately noticeable to all. Therefore, the team may need to work over or sometimes a new process may be needed if the implemented tactic is not effective.

\subsubsection{Financial Performance}

Performance entails the capability of an organisation to increase and manage its funds in diverse positive ways so as to develop competitive advantages (Iswatia \& Anshoria, 2007). Firm performance can also be described as how healthy an organization can apply its assets in other to generate revenue (Samina \& Ayub, 2013). It defines the technique that firms' resources, man, material, machine and money are utilized in other to maximizing organization objectives. Sometimes, performance and profit are used interchangeably, but there is clear difference between them. While profit is the overall revenue earned by an organization, performance refers to the capability of the organization to realize return on all the resources employed in business. Firm's performance is a concept that explains the proficiency of an organisation to be profitable in its dealing. It measures level of efficiency of a firm by using the available fund to achieve the projected profit goal.

\subsubsection{Risk management and Performance}

A poor firm performance results from inability of organisation to reduce, regulate, and evaluate risk. Practically, a good risk management capability will enhance performance, regular it valuations, and change in customers assumption, Muneer (2020). Risk management enabled business organisation to recognize, overview and control the exposures to risk from diverse area in other to enhance firm performance. Risk management also maximizes the organization value and guarantee that the benefits surpass the costs. The performance of the firm is strengthened by Risk management strengthen performance by reducing in unforeseen cost and positive development in risk culture of the organization (Teece, Peteraf, \& Leih, 2016).

Studies available on risk management and performance showed different opinions on the effect of firm performance on risk management. For instance, Ugwuanyi and Ibe (2012) assessed enterprise risk management and performance of Nigeria's brewery industry using primary data analyzed with simple percentages and z-statistics and found that $93 \%$ of respondent strongly agreed or agreed that business risk management could effectively enhance the operations of firms in Nigeria. Muneer (2020) also investigated enterprise risk management and performance of Pakistan manufacturing firms using primary data and concluded that organizations become enterprise risk management enhances organizational skill on operational and strategic decision making which as well increase performance. Other studies that found positive impact of risk management on performance among others include Mugenda et al. (2012); Yahaya et al. (2015); Madembu et al. (2015) and Soliman and Adam (2017).

\subsection{Theoretical Review}

\subsubsection{Liquidity Asset Theory}

Santomero (1984) viewed states liquidity risk theory as the theory that express risk arising from a firm having inability to convert asset to cash to meet it present obligation or demand as they fall due. Liquidity was also considered a financing crises risk. The credit in this situation means the possibility of lack of funding caused by inevitably situations or unexpected occurrence, such as huge charges off, hopelessness sell-off or currency crises. This theory explains that liquidity risk as a crisis arising due to funding problem.

\subsection{Empirical Review}

Olaniran, Namusonge, and Muturi (2016) analyzed role of risk-taking on performance of firms on Nigerian stock exchange. 60 sampled firms listed in Nigerian data were analysed using regression models including the Hausman specification test. The study showed a negative relationship between risk-taking and returns on assets 
likewise on risk-taking and returns on equity. Therefore, it was concluded that, Nigeria, risk-taking has widely implemented and used by entrepreneurial orientation dimension, but has not yet affect ROA and ROE positively.

Muneer (2020) investigated enterprise risk management and performance of Pakistan manufacturing firms. Primary data collected through questionnaire from 335 respondents was employed. The study then analyzed data using SEM-PLS. The study revealed a positive correlation between risk culture, innovativeness, and risk management information system and firm performance. Therefore, it was concluded that EMR has enhanced organizations operational and strategic decision making likewise performance by reduction of contingency losses.

Mugenda et al. (2012) assessed risk management practices and it effect on financial performance of sugar manufacturing enterprises in Kenya. Specifically, the causal link between risk management and financial performance adopted by sugar producing firms were assessed. Primary data collected was analyzed using Pearson correlation coefficient and analysis of variance. The result showed a significant variation in risk management practices within. Also, the study revealed above an average positive link om risk management practices and performance. Yahaya et al. (2015) evaluated the correlation between financial performance and risk management. The study particularly investigated the effect of business risk, firm risk, leverage, liquidity and firm size and age on return on asset and return on equity. The study employed panel data on 15 listed banks extracted for the period 2005-2014. The study analyzed data using regression analysis. The study revealed that the bank risk management mechanisms and liquidity policies positively affect organizational performance. A negative connection between bank financial leverage, size, age and financial performance was also shown. Therefore, it was concluded that risk and liquidity management policies are important for high financial performance.

Onuora and Ifeacho (2017) checked credit management effects on profitability of manufacturing firm in Nigeria. Impact of credit management mechanism: credit policy, liquidity management and debtors' turnover on return on asset was assessed. The study utilized five manufacturing firms' data from 2010 to 2014. Regression analysis was used in analysing the study. Result showed negatively significant correlation between credit policy and liquidity management and profitability proxy by Return on Assets also debtors' turnover has a significant and positive effect on Return on Assets.

Madembu et al. (2015) assessed role of risk management on financial performance of small and medium enterprises in Kenya. Particularly, impact of financial risk management, strategic risk management and operational risk management were investigated on financial performance of SMEs in Kenya. Secondary data collected from financial reports of 100 SMES were analysed using discursive method. The study then showed that SME risk management practices has effect on financial performance. Soliman and Adam (2017) investigated enterprise risk management and firm performance. The study measured performance model by the Return on Average Equity (ROAE), Share Price Return (SPR) and Firm Value (FV). The study employed secondary data on ten listed companies and regression analysis was employed to analyse data.A positively strong link between Enterprise Risk Management implementation and performance in the sector was discovered. Therefore, study concluded that firms that take on enterprise risk management achieve more than firms that have not taken it on. Ajibola et al. (2018) examined risk management and financial performance of deposit money banks in Nigeria. The study specifically investigated the impact of risk management (credit and liquidity) on financial performance of money deposit banks in Nigeria. The study employed panel data for 10 deposit money banks within Nigeria. The study analyzed data using panel regression. The study revealed a positive relationship exist between risk and financial performance of money deposit banks and risk management. Olalekan, Mustapha, Irom, and Emily (2018) evaluated corporate board size, risk management and financial performance of listed money banks in Nigeria. The study particularly examined effect of corporate board size, risk management on ROE and EPS of listed deposit money banks in Nigeria. Fourteen money bank data extracted over the period 2011-2016 was employed. The study analyzed data using panel regression. The study showed that variables significantly but negatively affect ROE and EPS respectively. Furthermore, it also revealed a negative but insignificant effect of ROE and EPS on liquidity risk in Nigeria banks. 
Efuntade and Akinola (2020) checked firm attributes and financial performance in listed manufacturing organisations in Nigeria. The study adopted data collated over the period 2005-2018. The study analyzed data using panel regression analysis. The study showed that Firm Size, Firm Age, Liquidity, Sales Growth and Leverage strongly and collectively have effect on return on asset of manufacturing firms in Nigeria. Therefore, the study concluded characteristics of firm related significantly with the return on asset. Erin et al. (2017) evaluated enterprise risk management and financial performance in the Nigerian financial sector. Forty companies' data between 2012 to 2016 were adopted. The study analyzed data using regression analysis. It was found that value at risk, board size, firm size and institutional ownership have positive effect on performance while leverage negatively affect performance.

Ironkwe and Osaat (2019) investigated risk asset management and financial performance of insurance companies in Nigeria. The study employed secondary data collated between 1986-2016. Johansen co-integration and error correction model were used to analysed data. The study showed in both short and long run ROE, ROA and leverage risk are all imperative factors in determining risk asset management in Nigeria

\section{DATA AND METHODS}

Ugah (2020) model was adopted for this study to assesses financial risk management and the profitability of firms. The study specified return on asset (ROA) as a function of liquidity risk (LQR), Credit risk, interest rate risk (INTR) and inflation rate risk (INFR) as presented in Equation 1.

$$
y_{i t}=\alpha_{0 i t}+\alpha_{1 i t} X_{i t}+u_{i t}
$$

Where y represents profitability measured in terms of return on asset, while $\mathrm{X}$ is a vector of risk management variables such as liquidity risk, credit risk, interest rate risk and inflation rate risk.

Given the focus of this study on the manufacturing firms the model specified in Equation 1 was modified by replacing return on asset with profitability in view of tracking the financial performance of the operation of the selected firms, while risk management variables captured as liquidity risk and interest rate risk (INTR) (replacing market risk), while firms size was included in the model as a control variable. hence model estimated for the study is presented in Equation 2.

$$
P A T_{i t}=\alpha_{0}+\alpha_{1} L Q R_{i t}+\alpha_{2} I N T R_{i t}+\alpha_{3} F Z_{i t}+u_{i t}
$$

Where PAT stands for profit after tax, LQR is liquidity risk INTR is interest rate risk and FZ is firm's size

\subsection{Scope, Sources of Data and Method of Analysis}

This captured quoted manufacturing firms in Nigeria stock exchange. Ten (10) manufacturing firms were purposively selected and data were collected from their annual reports between 2010 to 2019. Panel-based estimation techniques such as pooled OLS, fixed effect estimator, random effect estimator and evaluation for the most consistent estimator was done via restricted f-test and Hausman test to analysed data. While other post estimation test such as panel homoscedasticity test, autocorrelation test and cross-sectional dependence test were conducted to ascertain the fitness of the estimated model

Table-1. Correlation Matrix.

\begin{tabular}{c|c|c|c|c}
\hline & PAT & LQR & INTR & FZ \\
\hline PAT & 1.00000 & & & \\
\hline LQR & -0.5484 & 1.00000 & & \\
\hline INTR & 0.0178 & -0.1657 & 1.00000 & \\
\hline FZ & 0.7376 & -0.4743 & 0.1522 & 1.00000 \\
\hline
\end{tabular}




\section{DATA ANALYSIS AND DISCUSSIONS OF FINDINGS}

\subsection{Correlation Analysis}

Table 1 showed that there is positive correlation between interest rate risk and profit after tax but a negative correlation between liquidity risk and profit after tax of quoted firms selected in the study. The implication of this is that risk management has positive correlation with performance through the interest rate but negative correlation in terms of liquidity risk. In terms of magnitude, the result showed that the correlation between interest rate and profit after tax is weak, reflecting a weak level of movement of risk management and profit after tax of quoted firms. On the other hand, the result showed that correlation between liquidity risk and profit after tax, reflecting a strong level of movement of risk management and profit after tax of quoted firms selected in the study.

Table-2. Estimation result.

\begin{tabular}{l|l|l|l|l|l|l}
\hline Coefficient & Pooled & Prob & Fixed & Prob & Random & Prob \\
\hline C & -52.82031 & 0.065 & -50.99452 & 0.002 & -55.3316 & 0.001 \\
\hline LQR & -7.072336 & 0.000 & 3.200952 & 0.005 & 3.124137 & 0.006 \\
\hline INTR & -2.842544 & 0.062 & -.0820459 & 0.887 & -.399781 & 0.501 \\
\hline FZ & 6.594997 & 0.000 & 2.874586 & 0.004 & 3.787349 & 0.000 \\
\hline & R-square=0.6094 & R-square=0.9608 & R-square $=0.5903$ \\
& Adj R-square $=0.5972$ & Adj R-square $=0.9554$ & Wald chi $2(5)=17.5$ \\
& F-statistics=49.92 & F-statistics $=177.54$ & Prob $>$ chi2 $=0.000$ \\
& Prob(F-stat $)=0.0000$ & Prob(F-stat $)=0.0000$ & \\
\hline \multicolumn{7}{l}{ Restricted F-test $=(\mathrm{p}=<0.05)$} \\
\hline
\end{tabular}

Table 2 revealed estimations result of pooled OLS, fixed effect and random effect techniques, alongside restricted F-test and the Hausman test. In terms of reliability and proficiency it was established that of all the models used the most reliable and proficient is the fixed effect estimation, as such discussion shall be centered on the fixed effect estimation. As reported in Table 2, risk management in terms of liquidity risk positively and significantly affect performance of selected firms measured in terms of profit after tax. This result implies that one naira increases in current asset relative to current liability (or a naira decrease in current liability relative to current asset) will lead to about 3.20billion naira increase in profit after tax of quoted firms selected in the study. Furthermore, result presented showed that risk management in terms of interest rate has negative effect on performance in terms of profit after tax, a unit percent rise in interest rate will result to about o.osbillion increases in performance of quoted firms selected. Table 2 also presented R-square result of 0.6094 , reflecting that about $61 \%$ systematic variation in the performance of selected quoted firms clarified by risk management variables considering firm size, therefore, confirming the fitness of the model.

Table-3. Post Estimation Test.

\begin{tabular}{l|l|l}
\hline Wald test \\
\hline Null hypothesis & Statistics & Probability \\
\hline Panel homoscedasticity & 1.2731 & 0.2633 \\
\hline Pesaran test & Statistics & Probability \\
\hline Null hypothesis & 0.288 & 0.7731 \\
\hline No cross sectional dependence & \multicolumn{3}{|l}{} \\
\hline Wooldridge test & Statistics & Probability \\
\hline Null hypothesis & 1.5840 & 0.2399 \\
\hline No AR(1)panel autocorrelation
\end{tabular}

Table 3 result revealed that there is enough indication to reject null hypothesis on panel homoscedasticity, null hypothesis of no cross-sectional dependence and null hypothesis of no AR (1) panel autocorrelation, due to the statistics of $0.2633>0.5$ for Wald test, $0.7731>0.5$ for Pesaran test and $0.2399>0.5$ for Wooldridge test. 
Therefore, it can be exerted that expectations of equal variance of residual terms, cross sectional independence and nonappearance of serial autocorrelation for the predictable panel-based model is valid.

\subsection{Discussion of Findings}

The result showed that liquidity risk exerts positively significant effect on the performance of quoted firms in the study sampled measured in relations to profit after tax. This reflects that increase in a unit increase in liquidity risk will lead to about 3.20billion increase in profit after tax as measure of performance. The study was in agreement with the conclusion of Ajibola et al. (2018). Most of these firms have access to more current asset relative to current liabilities which make them avoid the risk of insolvency and encourage operational efficiency. The higher proportion of current asset relative to current liabilities especially through the cash and bank balances help these firms to have access to sufficient income required in the daily running of the business. the study showed that interest rate risk has negative effect on the performance of selected firms measured in terms of profit after tax. This showed that a percent rise in interest rate will lead to about 0.08 billion naira decrease in profit after tax in essence the result reflects that volatility in interest rate will dampen the prospect of increase level of profitability of manufacturing firms in the country, other things held constant.

\section{CONCLUSION AND RECOMMENDATIONS}

Risk management measures utilized in the study liquidity risk and interest rate risk have positive and negative effect on profit tax as measure of performance of the sampled quoted firms, but the effect of interest rate was found to be insignificant. While the liquidity can be directly influenced by the firm based on certain decisions, the interest rate can only be leveraged as it is autonomous to the firm. Therefore, this study concludes that efficient and effective risk management will positively and significantly affect performance of firms through effective and efficient management of liquidity in the quoted firms. Thus, this study recommends that manufacturing firms should device proper risk management structure that favours higher current asset. Also firms should build an internal control system flexible in nature to harness the benefit of internal risk management and also normalize the negative effect of external risk such as the interest rate on performance.

Funding: This study received no specific financial support.

Competing Interests: The authors declare that they have no competing interests.

Acknowledgement: Both authors contributed equally to the conception and design of the study.

\section{REFERENCES}

Acerbi, C. (2008). Pillar II in the new basel accord: The challenge of economic capital, chapter 9: Portfolio Theory in Illiquid Markets. London Risk Books.

Adeusi, S. O., Akeke, N. I., Adebisi, O. S., \& Oladunjoye, O. (2013). Risk management and financial performance of banks in Nigeria. European Journal of Business and Management, 6(31), 336- 341

Ajibola, A., Wisdom, O., \& Qudus, O. (2018). Capital structure and financial performance of listed manufacturing firms in Nigeria. Journal of Research in International Business and Management, 5(1), 81-89. Available at: https://doi.org/10.14303/jribm.2018.018.

Alarm. (2002). A risk management standard. UK: The Public Risk Management Association. AIRMIC, ALARM, IRM.

Antonio, B., \& Barbara, G. (2013). Risk management: How to assess, transfer and communicate critical risks. New York Dordrecht London: Springer Milan Heidelberg.

Coleman, S. (2006). Capital structure in small manufacturing firms: Evidence from the data. Journal of Entrepreneurial Finance, $J E F, 11(3), 105-122$. 
Efuntade, A. O., \& Akinola, A. O. (2020). Firm characteristics and financial performance in quoted manufacturing companies in Nigeria. International Journal of Business and Finance Management Research, 8(4), 26-32.

Erin, O., Emoarehi, E., Jonah, A., \& Ame, J. (2017). Enterprise risk management and financial performance: Evidence from emerging market. International Journal of Management, Accounting and Economics, 4(9), 937-952.

Ezeosa, D. (2011). The strategic implications of enterprise risk management: A framework. ERM symposium. United Kingdom: Coventry University.

Farrah, M. M. (2011). Assessing risk for strategy formulation in steel industry through real option analysis. Procedia-Social and Behavioral Sciences, 24, 991-1002. Available at: https://doi.org/10.1016/j.sbspro.2011.09.080.

Gallati, R. (2003). Risk management and capital adequacy. New York: McGraw-Hill.

Ironkwe, U. I., \& Osaat, A. S. (2019). Risk asset management and financial performance of insurance companies in Nigeria. International Journal of Advanced Academic Research/Accounting Practice, 5(4), 18-46.

Iswatia, S., \& Anshoria, M. (2007). The influence of intellectual capital to financial performance at insurance companies in Jakarta Stock Exchange (JSE). Paper presented at the Proceedings of the 13th Asia Pacific Management Conference. Melbourne, Australia.

Kassi, D. F., Rathnayake, D. N., \& Edjoukou, A. J. (2019). Market risk and financial performance of non-financial companies listed on the Moroccan stock exchange. China, Not Peer Review. Retrieved fom: https://www.preprints.org/manuscript/201901.0167/v1.

Koch, T. W., \& MacDonald, S. S. (2006). Bank management (pp. 562). United States of America: R. R. Donnelley \& Sons Company.

Madembu, A. W., Namusonge, G., \& Sakwa, G. N. (2015). The role of risk management on financial performance of small and medium enterprises in Kenya. International Journal of Science and Research, 6(1), 2125-2130.

Miller, L., Huelsman, T., Clark, B., \& Sokolovic, T. (2015). Understanding risk assessment practices at manufacturing companies. A collaboration between Deloitte and MAPI. Retrieved from: https://www2.deloitte.com/content/dam/Deloitte/us/Documents/manufacturing/us-mfg-mapi-riskassessmentpaper-single-page-040715.pd.

Mugenda, N. G., Momanyi, G., \& Naibei, K. I. (2012). Implications of risk management practices on financial performance of sugar manufacturing firms in Kenya. AFRREV IJAH: An International Journal of Arts and Humanities, 1(1), 14-29.

Muneer, S. (2020). Enterprise risk management and performance of Pakistan manufacturing firms: does the equity ownership matter. International Transaction Journal of Engineering Management, and Applied Sciences and Technologies, 11(8), 1-13.

Muriithi, J. G. (2016). Effect of financial risk on financial performance of commercial banks. Kenya Doctoral Dissertation, Cohred.

Njogo, B. O. (2012). Risk management in the Nigerian banking industry. Kuwait Chapter of the Arabian Journal of Business and Management Review, 1(10), 1-12.

Olalekan, L. I., Mustapha, L. O., Irom, I. M., \& Emily, B. N. (2018). Corporate board size, risk management and financial performance of Listed Deposit Money Banks in Nigeria. European Journal of Accounting, Auditing and Finance, 6(1), 1-20.

Olaniran, O., Namusonge, G. S., \& Muturi, W. (2016). The role of risk-taking on performance of firms on Nigerian stock exchange. International Journal of Research in Business Studies and Management, 3(3), 36-44.

Onuora, J. K., \& Ifeacho, S. N. (2017). The effects of credit management on profitability of manufacturing firms in Nigeria. A study of selected companies in Nigeria in stock exchange. Research Journal of Finance and Accounting, 8(4), 142-154.

Res, I. J. A., Sa, K., \& Gemechu, D. (2016). Risk management techniques and financial performance of insurance companies. International Journal of Accounting Research, 4(1), 1-5.

Samina, R., \& Ayub, M. (2013). The impact of bank specific and macroeconomic indicators on the profitability of commercial banks. The Romanian Economic Journal, 16(47), 91-110.

Santomero, A. (1984). Modeling the banking firm. Journal of Money, Credit, and Banking, 16(4), 576-602.

Soliman, A., \& Adam, M. (2017). Enterprise risk management and firm performance: An integrated model for the banking sector. Banks and Bank Systems, 12(2), 116-123. 
Stanton, T. H. (2012). Why some firms thrive while others fail: governance and management lessons from the crisis. New York: Oxford University Press.

Teece, D., Peteraf, M., \& Leih, S. (2016). Dynamic capabilities and organizational agility: Risk, uncertainty, and strategy in the innovation economy. California Management Review, 58(4), 13-35.

Ugah, J. (2020). Financial risks management and bank profitability in Nigeria. International Journal of Research and Innovation in Social Science, 4(9), 184-190

Ugwuanyi, U. B., \& Ibe, I. G. (2012). Enterprise risk management and performance of Nigeria's brewery industry. Developing Country Studies, 2(10), 60-67.

Van Staveren, M. (2009). Risk innovation and change. Design Propostions for Implenting Risk Management in Organisation. PhD Thesis. University of Twente, Enschede.

Yahaya, O. A., Lamidi, Y. S., Kutigi, U. M., \& Ahmed, M. (2015). The correlation between risk management and organizational performance: An empirical investigation using panel data. Research Journal of Finance and Accounting, 6(16), 136-147.

Yousfi, I. (2014). Risk management practices and financial performance in Jordan: Empirical evidence from Islamic Banks. International Shari'ah Research Academy for Islamic Finance, 6(5), 1-24. 